\title{
SUBTITUSI TEPUNG TALAS SEBAGAI PENGGANTI TEPUNG TERIGU PADA KUE TRADISIONAL BARONCONG
}

\section{Subtitution of Wheat Flour Into Taro Flour In Traditional Cake Baroncong}

\author{
Siti Hadijah ${ }^{1)}$, Dewi Andriani ${ }^{2}$ \\ ${ }^{1)}$ Program Studi Perhotelan, Politeknik Bosowa \\ ${ }^{2)}$ Program Studi Perhotelan, Politeknik Bosowa
}

18 November 2019

\begin{abstract}
Baroncong cake is traditional cakefrom Makassar city.It made from wheat flour with the addition of grated coconut, sugar, eggs, water and salt. This study aims to subtitute baroncong cake from Wheat flour into taro taro flour and to knows the panelis analyze result from hedonic test. This study uses formulations between taro flour and wheat flour with (100\% wheat flour and $0 \%$ taro flour), (75\% wheat flour and $25 \%$ taro flour), (50\% wheat flour and $50 \%$ taro flour), (25\% wheat flour and $75 \%$ taro flour), and (0\% wheat flour and $100 \%$ taro flour). The measured parameters were hedonic test (color, smell, texture and taste). The results showed that the treatment (75\% wheat flour and $25 \%$ taro flour) were preferred by panelist. It has the value average substitute taro flour in making baroncong cake with the value flavour 3.87, 3.7, and 3.87, taste 3.87, 3.82, and 3.79, tekstur 3.45, 3.55, and 3.76, and color 3.67, 3.61, and 3.66.
\end{abstract}

Keywords: Baroncong Cake, Taro Flour, Wheat Flour

\begin{abstract}
ABSTRAK
Kue baroncong adalah kue khas dari kota Makassar yang berbahan dasar tepung terigu dengan tambahan kelapa parut, gula, telur, santan dan garam. Penelitian ini bertujuan untuk menghasilkan kue baroncong dengan bahan substitusi tepung talas sebagai pengganti tepung terigu. serta mengetahui hasilpenilaianpanelismenggunakanujihedonikpada produk kue baroncong yang terbuatdaritepungtalas. Pembuatan kue baroncong ini menggunakan formulasi antara tepung talas dan tepung terigu, dengan perlakuan (100\% tepung terigu dan $0 \%$ tepung talas), (75\% tepung terigu dan $25 \%$ tepung talas), (50\% tepung terigu dan $50 \%$ tepung talas), ( $25 \%$ tepung terigu dan $75 \%$ tepung talas) dan ( $0 \%$ tepung terigu dan $100 \%$ tepung talas). Parameter yang diamati adalah ujihedonik (warna, aroma, tekstur dan rasa). Hasil penelitian menunjukkan produk kue baroncong tepung talas yang paling disukai terdapat pada perlakuan ( $75 \%$ tepung terigu dan $25 \%$ tepung talas) dengan penilaian rata-rata substitusi tepung talas dalam pembuatan kue baroncong yaitu aroma 3.87,3.7, dan 3.87, rasa 3.87, 3.82, dan 3.79, tekstur 3.45, 3.55, dan 3.76, dan warna 3.67, 3.61, dan 3.66.
\end{abstract}

Kata kunci: Kue Baroncong, Tepung Talas, Tepung Terigu

\section{PENDAHULUAN}

\section{1) Latar Belakang}

Kekayaan kuliner Indonesia merupakan salah satu bagian dari budaya Indonesia. Kuliner tradisional saat ini semakin diminati dengan banyaknya modifikasi dalam bahan dasar dan serta penambahan berbagai pelengkap untuk memperkaya rasa dari kue-kue tradisional. Makassar memiliki berbagai jenis kue tradisional yang sampai saat ini masih banyak diminati oleh berbagai kalangan. Salah satu kue tradisional yang ada di Makassar yaitu kue baroncong. Kue ini terbuat dari tepung terigu yang dicampur dengan parutan kelapa muda, gula dan garam, dengan bentuk setengah lingkaran. Proses pembuatan kue baroncong adalah dengan memanggangnya dalam cetakan diatas bara api yang berasal dari kayu bakar. Melalui penelitian ini akan dilakukan subtitusi tepung talas terhadap bahan utama pada kue baroncong yaitu tepung terigu. Subtitusi dilakukan sebagai salah satu langkah dalam mengurangi ketergantungan terhadap tepung terigu bagi masyarakat Indonesia sehingga dapat meningkatkan nilai jual hasil pertanian Indonesia, seperti jenis umbi-umbian yang memiliki banyak jenis dan dapat diolah menjadi berbagai bahan pembuatan dalam masakan dan kue.

Talas merupakan salah satu dari jenis umbiumbian sebagai pangan sumber karbohidrat yang prospektif untuk dikembangkan dalam usaha komersial. Selain telah lama dikenal dan 
ditanam masyarakat Indonesia, tanaman talas juga memiliki peran penting dalam peningkatan ketahanan dan kedaulatan pangan, penganekaragaman komsumsi pangan lokal, substitusi tepung gandum atau terigu, pengembangan agroindustri pangan, peningkatan pendapatan petani dan kecukupan gizi masyarakat serta sebagai komoditas strategis pemasok devisa negara melalui ekspor.

Talas termasuk 10 makanan yang kaya vitamin $\mathrm{E}$, vitamin ini bermanfaat bagi tubuh, di antaranya mampu melindungi diri dari sinar ultraviolet, mencegah kerusakan sel dari radikal bebas, menurunkan risiko kanker prostat dan penyakit Alzheimer[1]. Dalam bentuk tepung, talas memiliki komposisi nutrisi yang lebih baik di banding beras. Pada kadar air yang relatif sama, tepung talas mengandung protein yang lebih tinggi dan kadar lemak yang lebih rendah dari beras.

Talas lebih mudah dicerna sehingga dapat dijadikan bahan makanan bagi balita dan lanjut usia. orang lanjut usia dan orang yang bermasalah dengan saluran pencernaan[2]. Pemilihan subtitusi tepung talas terhadap tepung terigu dalam pembuatan kue baroncong adalah satu variasi dalam pembuatan kue tradisional sehingga dapat menambah nilai jual dan banyaknya kandungan vitamin sehingga kue tradisional dapat menjadi salah satu alternatif makanan sehat.

\section{2) IdentifikasiMasalah}

a. Bagaimana proses pembuatan Umbi Talas menjadi tepung talas?

b. Bagaimana daya terima masyarakat terhadap kue baroncong yang berbahan dasar tepung talas?

\section{3) Tujuan Penelitian}

Adapun tujuan penelitian adalah mengetahui pembuatan umbi talas menjadi tepung talas dan mengukur daya terima masyarakat terhadap Kue baroncong yang berbahan dasar tepung talas.

\section{LANDASAN TEORI}

\section{1) Umbi talas}

Umbi talas terletak di bagian bawah pokok batang talas. Umbi inilah yang dimanfaatkan sebagai bahan makanan. Ada bermacam jenis talas, baik yang liar maupun yang dibudidayakan. Bahkan ada jenis tertentu yang ditanam sebagai tanaman hias. Jenis talas dapat dicirikan oleh warna daun dan tangkainya. Selain itu tanaman talas juga dibedakan berdasarkan warna dan rasa yang tergantung pada jenis talas [3].

Pada100 gram talas kukus tanpa bumbu terkandung 142 kalori dan serat 5,3 gram. Komponen karbohidrat dalam talas berupa pati mencapai 77,9 persen. Kandungan amilopektin yang tinggi dalam talas menjadikan rasa dan tekstur talas lengket dan pulen, seperti beras ketan. Pati talas mudah dicerna sehinggah cocok dijadikan makanan lansia atau diet pasca sakit.

Kandungan seratnya memenuhi $20,5 \%$ kebutuhan serat sehari. Serat sangat bagus untuk memperlancar kerja pencemaan. Kandungan nutrisi lain dalam talas adalah protein. Setiap 100 gram talas mengandung 1,9 gram protein. Kandungan protein dalam talas berupa asam amino esensial[4]. Manfaat utama umbi talas adalah sebagai bahan pangan sumber karbohidrat.

Di beberapa daerah seperti di Papua Barat, talas dikonsumsi sebagai makanan pokok. Selain itu umbi talas juga dapat dimanfaatkan sebagai bahan makanan tradisional, tepung talas (bahan pembuat roti, kue, zat pengental, dan makanan bayi), obat tradisional (encok, rematik, bisul, penawar racun, dan obat urusurus), dan produk fermentasi berupa pasta kental yang disebut poi. Tetapi karena kandungan karbohidrat yang cukup tinggi serta adanya kandungan nutrisi lainnya, kini talas lebih banyak dibudidayakan sebagai salah satu makanan untuk diversivikasi pangan. (Departemen Pertanian dalam Kafah. 2012)

Umbi talas memiliki kandungan potensi karbohidrat dan protein, mineral $\mathrm{Ca}$ dan $\mathrm{P}$ yang cukup tinggi, kedua mineral tersebut penting bagi pembentukan tulang dan gigi yang kuat. Selain itu pula mengandung vitamin A, C, sedikit B1 (Rukmana dalamKafah. 2012). Seperti yang dikutip dari Pranowo dalam Kafah. 2012), tepung talas memiliki kandungan gizi yang baik dibandingkan dengan tepung umbi lainnya. Tepung talas mengandung serat yang sangat berguna membantu pencemaan makanan dalam tubuh. Hal ini mengakibatkan dengan mengkonsumsi tepung talas dapat mencegah seseorang terserang penyakit wasir, ambeien atau haemorroid [3]. 


\section{2) Kue baroncong}

Kue baroncong adalah kue tradisional khas dari kota Makassar Sulawesi Selatan yang cukup diminati di kalangan masyarakat makassar, bentuk dari kue baroncong adalah setengah lingkaran, bentuk dari kue Baroncong ini mirip dengan kue bandros jakarta. Ciri khas dari kue baroncong yaitu rasa yang gurih. Kue baroncong ini dibuat dari bahan utama, tepung terigu, kelapa parut, gula, garam dan kuning telur. Adapun karakteristik kue baroncong adalah:

a. Warna dari kue baroncong yaitu bagian luar berwarna agak coklat, bagian atas kue baroncong berwarna putih pucat

b. Tekstur bagian luar kue baroncong yaitu kering dan bagian atas yang lembek.

c. Aroma kue baroncong mempunyai aroma kelapa yang khas.

d. Rasa dari kue baroncong yang agak manis dan gurih.

\section{3) Telur}

Telur ayam merupakan jenis telur yang sering digunakan untuk membuat kue. Pilih telur yang masih baru, tidak retak, dan tidak ada kotoran yang menempel. Telur yang baru ditandai dengan putih telur yang masih kental dan kuning telur masih bulat utuh. Fungsi telur dalam pembuatan kue baroncong berguna sebagai pengikat bahan - bahan lain, memberikan kelembapan, menambah nilai gizi, memberikan rasa gurih, dan membuat aroma kue baroncong lebih harum. Kuning dan puth telur mempunyai sifat masing - masing.

Kuning telur lebih untuk merenyahkan tekstur, sedangkan putih telur akan mengikat tepung sehingga adonan akan lebih padat dan tidak renyah]. Cara penggunaan telur pada pembuatan kue baroncong adalah kuning telur dimasukkan kedalam adonan sambil diaduk hinggah rata. [5]

\section{4) Kelapa Parut}

Varietas kelapa yang digunakan sebagai kelapa parut pada pembuatan kue baroncong substitusi tepung talas yaitu kelapa varietas hibrida karena varietas kelapa ini apabila digunakan dalam pembuatan suatu makanan tidak merubah warna asli makanan yang dibuat. Kelapa sering digunakan dalam pembuatan kue tradisional dalam bentuk kelapa parut, cincang, atau dalam bentuk santan. Penambahan kelapa akan membuat kue yang dihasilkan semakin gurih. Kelapa parut biasanya digunakan sebagai bahan taburan, isian, maupun bahan campuran dalam adonan kue tradisional Indonesia [6].

Kelapa parut sebagai salah satu bahan dalam pembuatan kue baroncong yang berfungsi untuk membentuk tekstur kue baroncong yang khas yaitu adanya serat kasar

\section{5) Gula}

Gula adalah karbohidrat murni yang tidak tersusun atas nutrien lainnya seperti lemak, protein, mineral, dan vitamin. Gula merupakan makanan penting sebagai sumber kalori yang mudah dicerna. Selain sebagai makanan dan pemberi rasa manis gula juga sebagai bahan pengawet makanan [7]. Gula yang biasa digunakan adalah gula pasir. Pilih gula pasir yang berbutiran halus dan berwarna putih bersih. Pemilihan gula pasir berfungsi agar tidak mempengaruhi warna pada kue baroncong.

6) Air

Air merupakan komponen terpenting dalam proses pembuatan kue, karena hanya dengan air dimungkinkannya terjadi suatu adonan. Air juga dapat mempengaruhi penampilan, tekstur, serta cita rasa makanan. Penggunaan air dalam pembuatan produk harus disesuaikan dengan adonan karena penggunaan air yang terlalu sedikit dapat menyebabkan adonan menjadi keras apabila terlalu banyak akan sulit dibentuk.

\section{PENELITIAN TERDAHULU}

Penilitian sebelumnya dilakukan oleh Asty Dewi Pangaribuan pada tahun 2013 dengan judul Substitusi Tepung Talas Belitung Pada Pembuatan Biskuit Daun Kelor (Moringa oleifera Lamk) [8]. Salah satu upaya untuk mengurangi ketergantungan tepung terigu dalam pembuatan biskuit adalah mengolah bahan lain untuk mensubstitusi tepung terigu. Salah satu produk lokal yang bisa diolah adalah talas belitung karenaberpotensi sebagai sumber karbohidrat yang cukup tinggi. Selain melakukan substitusi, dilakukan juga penambahan daun dari tanaman kelor (Moringa oleifera Lamk). Daun kelor mengandung serat, vitamin $\mathrm{C}$ dan mineral yang cukup tinggi. Dengan penelitian ini diharapkan akan memberikan inovasi rasa biskuit yang berbeda dengan biskuit yang ada dipasaran.

Tujuan penelitian ini adalah untuk mengetahui pengaruh substitusi tepung talas belitung yang tepat untuk menghasilkan biscuit dengan kualitas paling baik dilihat dari sifat 
kimia, fisik, mikrobiologis dan organoleptiknya. Penelitian ini menggunakan Rancangan Acak Lengkap (RAL) dengan 6 variasi tepung talas belitung sebesar $0 \%$ (kontrol), 30, 40, 50, 60 dan $70 \%$ dengan penambahan serbuk daun kelor sebanyak dua gram tiap perlakuan. Dilakukan berbagai anaisis yang meliputi kadar air, abu, lemak, protein, karbohidrat, serat kasar, vitamin C, uji tekstur, angka lempeng total, perhitungan kapang khamir, dan uji organoleptik. Analisis data secara statistik dengan ANAVA pada $\alpha=$ 5\% dan dilanjutkan dengan DMRT bila ada beda nyata. Hasil analisis menunjukkan bahwa substitusi tepung talas belitung meningkatan kadar abu, karbohidrat, serat dan tekstur biskuit tetapi menurunkan kadar air serta lemak, dan protein. Biskuit daun kelor dengan substitusi $70 \%$ tepung talas belitung memiliki kualitas paling baik ditinjau dari sifat kimia dan organoleptiknya.

Penelitian juga dilakukan oleh Rosalin Putri Khotmasari dengan judul Pengaruh Substitusi Tepung Talas Belitung (Xanthosoma Sagittifolium) Terhadap Tingkat Pengembangan dan Daya Terima Donat [9]. Pada tahun 2013 dengan hasil pembahasan Penelitian pendahuluan dilakukan bertujuan untuk menentukan variasi perbandingan

Penelitian pendahuluan dilakukan bertujuan untuk menentukan variasi perbandingan antara tepung terigu dan tepung talas belitung terhadap warna, aroma, rasa, tekstur dan keseluruhan dalam pembuatan donat. Penelitian pada pendahuluan uji daya terima pada panelis dilakukan dengan subtitusi tepung talas belitung $20 \%$ dan $40 \%$ dari tepung terigu. Hasil daya terima yang paling disukai secara keseluruhan adalah pada daya terima dengan subtitusi tepung talas belitung $20 \%$,di bandingkan dengan subtitusi $40 \%$, sehingga range subtitusi tepung talas belitung untuk penelitian utama adalah $10 \%$, dan $20 \%$.

\section{METODE PENELITIAN}

\section{1) Waktu dan Lokasi Penelitian}

Penelitian ini dilaksanakan pada beberapa tempat di Kota Makassar dimana banyakremaja umur 18-25 tahun karena adanya kesadaran akan makanan sehat tidak lagi hanya dilaksanakan pada lansia.

Adapun dua lokasi berbeda yang dipilih adalah Kampus Politeknik Bosowa Makassar yang berlokasi di jalan Kapasa Raya No. 23
Kima, Makassar-Sulawesi Selatan dan Universitas Bosowa Makassar dengan lokasi jalan Urip Sumoharjo kilometer 4 Panakukkang, Makassar Sulawesi Selatan.

Penelitian dilaksanakan mulai bulan Februari sampai dengan Agustus.

\section{2) Jenis dan Sumber Data}

Data primer dalam penelitian ini diperoleh dari hasil olahan data kuesioner yang dibagikan kepada panelis tentang daya terima masyarakat dari aspek rasa, aroma, tekstur dan warna. Data sekunder yaitu data yang didapat dari catatan, buku, majalah berupa laporan keuangan publikasi perusahaan, laporan pemerintah artikel, buku-buku sebagai data pendukung [10]. Data Sekunder dalam penelitian berupa informasi tentang hasil panen umbi talas di Sulawesi Selatan dan berbagai definisi jenis-jenis nutrisi di dalam umbi talas.

\section{3) Populasi dan Sampel}

Populasi di dalam penelitian ini adalah remaja umur 18-25 tahun di dua kampus yaitu Politeknik Bosowa dan Universitas Bosowa yang kemudian didapatkan hasil sampel melalui perhitungan rumus slovin adalah sekitar 160 orang.

\section{4) Teknik Pengumpulan Data}

Pada penelitian "substitusi tepung talas terhadap tepung terigu pada kue baroncong", penulis menggunakan metode analisis kuantitatif. Metode analisis kuantitatif adalah kegiatan analisis yang dilakukan setelah pengumpulan data dari responden. Kegiatan dalam analisis adalah mengelompokkan data berdasarkan variabel dan jenis responden, mentabulasi data berdasarkan variabel dari seluruh responden, menyajikan data tiap variabel yang diteliti, melakukan perhitungan untuk menjawab rumusan masalah, dan melakukan perhitungan untuk menguji hipotesis yang telah diajukan. Untuk penelitian yang tidak merumuskan hipotesis, langkah terakhir tidak dilakukan [11].

Penelitian ini melakukan uji hedonik atau uji kesukaan dengan cara memberikan beban kepada panelis kemudian meminta tanggapan suka atau tidak suka (Sugiyono. 2016). Panelis diminta memberikan pendapat dengan tanggapan nilai 5 yaitu sangat suka, 4 adalah suka, 3 yaitu kurang suka, 2 adalah tidak suka dan 1 adalah sangat tidak suka. 
Pengumpulan data melalui angket dilaksanakan sebanyak 3 kali untuk masingmasing perlakuan 1,2 dan 3. Nilai dari setiap jawaban pada setiap perlakuan dijumlahkan kemudian dibagi seluruh panelis yang mengikuti penilaian sehingga diperoleh nilai rata-rata yang dapat dicocokan dengan kriteria penilaian.

\section{5) Alat dan Bahan}

Bahan dan alat pembuatan produk adalah hal penting yang tidak dapat lepas dari proses produksi. Tanpa bahan dan alat produksi, proses produksi tidak akan dapat berjalan. Bahan yang digunakan dalam pembuatan produk penelitian mempunyai spesifikasi yang baik. Bahan yang baik akan membuat produk yang dihasilkan baik pula. Bahan-bahan yang digunakan dalam pembuatan kue baroncong adalah:

a. Tepung talas 250 gram

b. Kelapa parut 250 gram

c. Gula 200 gram

d. Garam secukupnya

e. Kuning telur satu butir

f. Air $500 \mathrm{ml}$

Adapun alat pembuatan yang penulis gunakan adalah:

a. Scale

Alat untuk mengukur berat bahan-bahan yang akan digunakan dalam pembuatan produk. Agar sesuai dengan takaran yang diinginkan (sesuai resep).

b. Mixing Bowl

Digunakan untuk mencampur bahan. Biasanya terbuat dari plastik, stainless steel, kaca maupun porselen.

c. Balloon whisk

Balloon wishk digunakan untuk mencampur adonan.

d. Baroncong Mould

Baroncong mould adalah cetakan yang berbetuk setengah lingkaran untuk mencetak adonan baroncong.

e. Stove

Stove adalah kompor yang digunakan untuk membuat adonan baroncong menjadi matang.

\section{HASIL PENELITIAN}

Pembuatan Tepung Talas penulis bagi menjadi 3 tahap yaitu tahap persiapan, tahap pelaksanaan dan tahap penyelesaian. Tahap persiapan pada pembuatan baroncong ini adalah persiapan alat dan persiapan bahan.

a. Persiapan alat

Penulis menyiapkan semua peralatan berupa mixing bowl, balloon whisk, kompor gas, cetakan kue baroncong dan timbangan.

b. Persiapan bahan

Siapkan bahan-bahan yang dibutuhkan, berupa umbi talas yang akan diolah menjadi tepung serta bahan lainnya dalam pembuatan kue baroncong. Timbang setiap bahan sehingga diketahui berapa jumlah tepung yang dihasilkan per satu kali proses pembuatan umbi talas. Timbang bahan-bahan pembuatan kue baroncong sesuaikan dengan resep baku yang telah dipilih.

Tahap pelaksanaan adalah tahap dimana tahap pembuatan tepung talas yang penulis dapatkan dari berbagai sumber adalah sebagai berikut:

1. Kupas kulit umbi talas sampai bersih, cuci bersih dengan air mengalir dan tiriskan hingga kering. Umbi talas yang dicuci bersih dapat menghasilkan tepung yang berwarna putih dan cerah.

2. Iris umbi talas dengan ketebalan sekitar 0,3 - 0,4 cm menggunakanpisau atau slicer untuk mempertahankan ketebalan

3. Rendam irisan talas di dalam air yang telah diberi baking powder sebanyak 1 sendok makan untuk 10 liter air, hal tersebut bertujuan untuk menghilangkan getah. Perendaman dilakukan selama lebih kurang 1 jam.

4. Talas dikukusselama 10 menit yang bertujuan untuk mencegah terjadinya perubahan warna sehingga warna asli dapat dipertahankan.

5. Masukkan talas yang sudah dikukus ke tempat yang telah diisi air serta Sodium Metabisulfit (SMS) 1 sendok untuk 10 liter air. SMS bertujuanuntuk mencegah adanya perubahan warna menjadi kecoklatan atau warna menjadi pucat. Setelah direndam selama kurang lebih 30 - 60 menit angkat irisan talas.

6. Keringkan di bawah sinar matahari atau dapat silakukan dengan dengan oven gunakan suhu yang tidak terlalu panas untuk mencegah talas menghitam. Selama proses pengeringan bolak-balik hingga cukup kering mudah dipatahkan.

7. Tumbuk atau giling talas hasil pengeringan hingga menjadi tepung, gunakan alat penggiling yang bagus sehingga tepung dapat haslus dengan sempurna. Proses ini 
dilanjutkan dengan talas dipercikan air dan didiamkan kurang lebih 5-10 menit untuk menghasilkan tepung yang lebih baik.
Setelah mendapatkan hasil tepung talas proses selanjutnya adalah pembuatan kue baroncong dengan perlakuan pada table 1 .

8. Saring tepung talas dengan ayakan hingga mendapatkan hasil tepung yang lebih halus.

\begin{tabular}{cccccc}
\hline Bahan & Kontrol & Perlakuan 1 & Perlakuan 2 & Perlakuan 3 & Perlakuan 4 \\
\hline Tepung Talas & $0 \%$ & $25 \%$ & $50 \%$ & $75 \%$ & $100 \%$ \\
\hline Tepung Terigu & $100 \%$ & $75 \%$ & $50 \%$ & $25 \%$ & $0 \%$ \\
\hline \multicolumn{5}{c}{ Tabel 1. Perlakuan Subtitusi Kue Baroncong } \\
Sumber: Dokumentasi Penulis
\end{tabular}

Adapun pada tabel 1 diuraikan bahwa perlakukan subtitusi kue baroncong padakolom control yaitu resep baku dimana $100 \%$ kue baroncong yang dibuat dari tepung terigu.

- Perlakuan 1 menjelaskan bahwa komposisi tepung talas $25 \%$ dan tepung terigu $75 \%$,

- perlakuan 2 komposisi tepung talas $50 \%$ dan tepung terigu $50 \%$,

- perlakuan 3 dengan komposisi tepung talas $75 \%$ dan tepung terigu $25 \%$ dan,

- perlakuan 4 komposisi tepung talas $100 \%$ dan tepung terigu $0 \%$.

Pada proses uji hedonik 160 panelis dari aspek rasa, aroma, warnadan tekstur yang dibagi pada 3 kali uji coba, didapatkan hasil pada aspek aroma yang diuraikan pada gambar 1 .

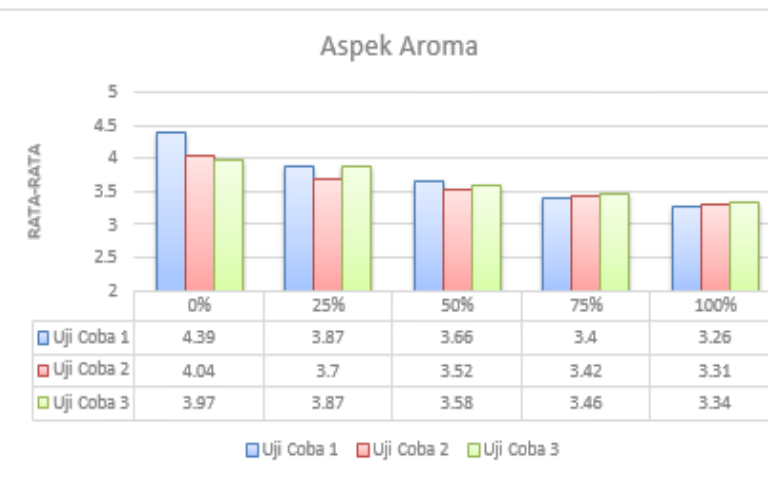

Gambar.1, Aspek Aroma

Sumber: Dokumentasi penulis

Berdasarkan gambar. 1 jenis perlakuan kue baroncong yang mendapat nilai paling baik terdapat pada konsentrasi kue baroncong $25 \%$ dengan rata-rata penilaian panelis pada tiap uji 3.7. Pada ujicoba 1 di peroleh nilai 3,87 , ujicoba 2 diperoleh nilai 3,7 dan ujicoba 3 diperoleh nilai 3,87 .

Hasil penilaian panelis terhadap aspek aroma kue baroncong bahwa tepung talas memberikan pengaruh terhadap aroma kue baroncong. Hal tersebut dibuktikan dengan hasil penilaian aspek aroma panelis yang didapatkan dari uji coba pertama hingga uji coba ketiga. Pada gambar 2 diuraikan hasil analisis data panelis pada ujicoba 1,2 dan 3 dalam aspek rasa.

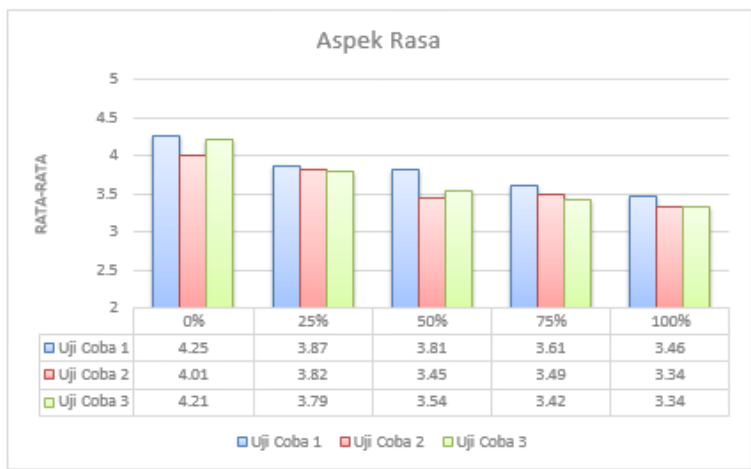

Gambar.2, Aspek Rasa

Sumber: Dokumentasipenulis

Berdasarkan gambar 2., jenis perlakuan kue baroncong yang mendapat nilai yang paling baik terdapat pada konsentrasi kue baroncong $25 \%$ dengan penilaian panelis pada tiap uji coba rata-rata 3.79 yaitu pada uji coba 1 diperoleh nilai 3,87 , uji coba 2 diperoleh nilai 3,82 dan uji coba 3 diperoleh nilai 3,79 hasil penilaian panelis terhadap aspek rasa kue baroncong, memberikan pengaruh terhadap rasa kue baroncong.

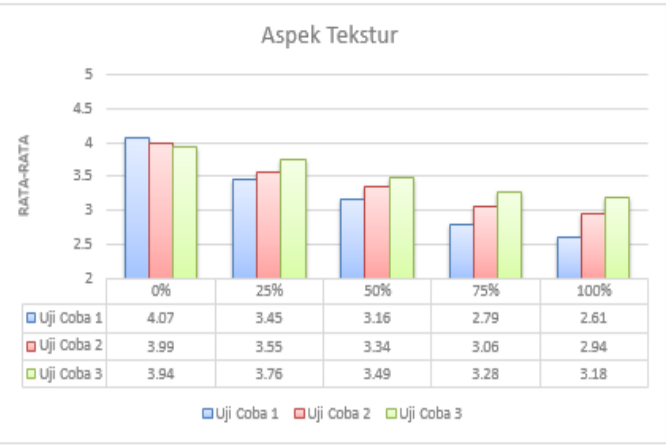

Gambar.3, Aspek Tekstur Sumber: Dokumentasipenulis 
Berdasarkan gambar 3 jenis perlakuan kue baroncong yang mendapat nilai yang paling baik terdapat pada konsentrasi tepung talas $25 \%$ dengan penilaian panelis pada tiap ujicoba diatas rata-rata 3.45 yaitu pada ujicoba 1 diperolehnilai 3,45 , ujicoba 2 diperoleh nilai 3,55 dan uji coba 3 diperoleh nilai 3,76 .

Jika dilihat dari hasil penilaian panelis terhadap aspek tekstur kue baroncong, dapat disimpulkan bahwa tepung talas memberikan pengaruh terhadap tekstur kue baroncong. Pada gambar 4 diuraikan hasil penilaian panelis pada ujicoba 1,2 dan 3

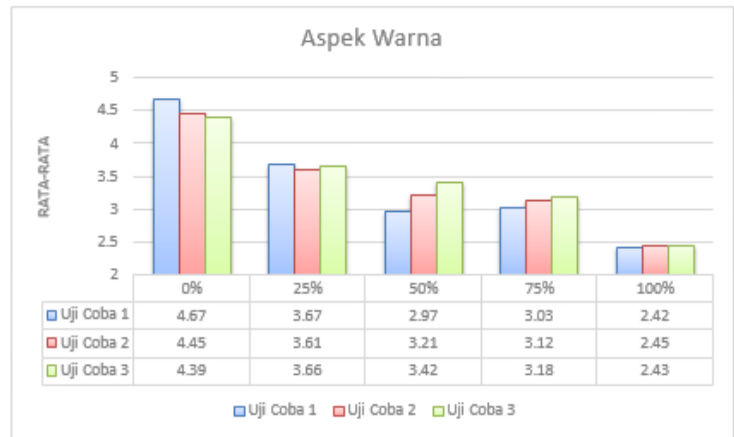

Gambar.4, Aspek Warna

Sumber: Dokumentasipenulis

Berdasarkan gambar 4 jenis perlakuan kue baroncong yang mendapat nilai paling baik dari panelis terdapat pada konsentrasi tepung talas $25 \%$ dengan penilaian panelis pada tiap uji coba 3.61 yaitu pada uji coba 1 diperoleh nilai 3,66 , uji coba 2 diperoleh nilai 3,61 dan uji coba 3 diperoleh nilai 3,66 .

dari hasil penilaian panelis terhadap aspek warna kue baroncong dapat disimpulkan bahwa tepung terigu memberikan pengaruh terhadap warna kue baroncong.

Dari penilaian panelis pada setiap aspek tepung talas memiliki pengaruh akan tetapi melalui penilaian tersebut terlihat bahwa panelis lebih menyukai kue baroncong dengan $100 \%$ tepung terigu (control) sehingga pembiasaan terhadap bahan pangan alternative tentu saja harus lebih ditingkatkan.

\section{SIMPULAN}

a. Produk kue baroncong substitusi tepung talas dapat diolah dengan baik, setelah penulis melakukan uji coba sebanyak tiga kali di kampus Politeknik Bosowa dan Universitas Bosowa,

b. Dalam pembuatan kue baroncong substitusi tepung talas tidak mengalami perubahan yang jauh berbeda dari segi aroma, rasa, dan tekstur dengan kue baroncong yang menggunakan $100 \%$ tepung terigu, sebagaimana kita lihat hasil penilaian ratarata penelis untuk aroma pada setiap uji coba yaitu 3,34-3.83 (suka), sedangkan pada rasa mendapatkan nilai rata-rata 3.30-3.81 (suka), dan pada tekstur mendapatkan nilai rata-rata yaitu 2.71 - 3.59 (agak suka-suka), akan tetapi perubahan yang jauh berbeda dilihat dari segi warna dengan nilai rata-rata pada setiap perlakuan yaitu $3.65,3.20,2.68$, 2.58. Hal ini disebabkan perbedaan wama dari tepung talas yang berwarna ungu.

c. Produk kue boroncong substitusi tepung talas dapat diterima oleh konsumen setelah peneliti melakukan uji coba selama 3 kali dengan penilaian penelis pada aspek aroma, rasa, tekstur, warna. Penelis memberikan penilaian dari agak suka sampai suka. Perlakuan yang paling disukai oleh penelis yaitu pada kue baroncong penambahan tepung talas $25 \%$.

\section{DAFTAR PUSTAKA}

Edward, J. 2014. Seri Belajar Memasak Kue Tradisional. Demedia Pustaka. Jakarta.

Harry,wiedy. Sumber Buku Pencernaan

Sebagai Kunci Hidup Sehat, Alice M.

Sorokie, diterjemahkan dari judul aslinya

Gut Wisdom.

Kafah Fiki Fitriya Silmi. 2012. Karakteristik

Tepung Talas (Colocasia Esculenta (L)

Schott) dan Pemanfaatannya Dalam

Pembuatan Cake. Skripsi Teknologi pertanian pada Departemen Teknik

Mesin Dan Biosistem Fakultas

Teknologi Pertanian Institut Pertanian Bogor

Khotmasari Rosalin Putri. 2013.Pengaruh

Substitusi Tepung Talas Belitung (Xanthosoma Sagittifolium) Terhadap

Tingkat Pengembangan dan Daya

Terima Donat. Universitas

Muhammadiyah Surakarta fakultas Ilmu 
Kesehatan Program Studi Diploma III

Ilmu Gizi. Surakarta.

Kristayani, W. 2012. Pemamfaatan Tepung Ubi

Ungu Dalam Pembuatan produk Patiseri

Program Studi Teknik Boga Fakultas

Teknik Universitas Negri Yogyakarta.

Muchtadi Tien Ruspriatin, Sugiyono. 1992.

Ilmu Pengetahuan Bahan Pangan.

DepdikbudDikjen DIKTI, PAU

Pangandan Gizi, IPB. Bogor.

Pangaribuan Asty Dewi. 2013. Subtitusi

Tepung Talas Belitung Pada Pembuatan

Biskuit Daun Kelor (Moringa oleifera

Lamk). Universitas Atmajaya

Yogyakarta Fakultas Teknobiologi

Program Studi Biologi. Yogyakarta

Rukmanan, Rahmat. 2015. Untung Berlipat

dari Budi daya talas-Tanaman Multi

Manfaat. Lilhy Publisher. Yogyakarta.

Sugiyono, 2015. Metode Penelitian Kuantitatif

Kualitatif Dan R \& D. Bandung.

Alfabeta.

Sujarweni, V. 2014. Metodologi Penelitian. PT

Pustakabarupress. Yogyakarta

Sutomo, B. 2008. Sukses Wirausaha Kue

Kering. Kriya Pustaka. Jakarta 